\title{
Efficient Biolistic Transformation and Regeneration Capacity of an EgTCTP Transgene in Protocorm-like Bodies of Phalaenopsis Orchid
}

\author{
Kantamaht KANCHANAPOOM ${ }^{1 *}$,Alisa NAKKAEW ${ }^{1}$, Kamnoon \\ KANCHANAPOOM ${ }^{2}$, Amornrat PHONGDARA ${ }^{1}$ \\ ${ }^{1}$ Prince of Songkla University, Center for Genomics and Bioinformatics Research, Hat Yai, Songkhla, \\ 90112, Thailand; kantamabt@hotmail.com (*corresponding author) \\ ${ }^{2}$ Prince of Songkla University, Department of Biology, Faculty of Science, Hat Yai, Songkhla 90112, Thailand
}

\begin{abstract}
An efficient genetic transformation system using the biolistic method and protocorm-like bodies (PLBs) of Phalaenopsis orchid was established for introducing the EgTCTP gene obtained from oil palm leaves. A pCAMBIA 1302 vector containing the green fluorescent protein $(m g f p 5)$ as reporter gene and the selectable marker hygromycin phosphotransferase ( $h p t)$ gene under the cauliflower mosaic virus (CaMV) 35 S promoter were used in this experiment. The transformed PLBs were cultured on MS medium containing 20 $\mathrm{mg} / \mathrm{L}$ hygromycin for 2 months. The surviving PLBs with green fluorescence spots were used to calculate a transformation frequency (93.34\%). PLBs containing the transformed EgTCTP gene had the highest percentage of regeneration frequency (95.66\%) and numbers of regenerated shoots per explant $(3.78 \pm 1.89$ shoots) compared to the control. The time required for initiation of primordial shoots in the transformed PLBs (55.22 \pm 26.56 days) was much shorter than for the control. Evaluation of the regeneration efficiency, determined that the status of the EgTCTP transformants was above average: score $=4.04 \pm 0.88$. The EgTCTP gene was detected in the PLBs over a period of at least 6 months with subculturing every 4 weeks. The stability of the transgenes within the PLBs was confirmed by PCR and this indicated that the transgenes had been integrated into the genome of the transformants. This is the first successful report to introduce EgTCTP gene into PLBs of Phalaenopsis orchid.
\end{abstract}

Keywords: hygromycin, $m g f p 5$ gene, pCAMBIA 1302, PCR, transgenic plant, translationally controlled tumor protein

\section{Introduction}

Phalaenopsis, a member in the family Orchidaceae, is one of the most popular epiphytic orchids with high economic value in the orchid trade all over the world. It is noted for its good form, beauty, long-lasting flowers and long inflorescence which make it eminently suitable for ornamental plants. Nowadays genetically transformed plants of a Phalaenopsis orchid have been developed from both Agrobacterium-mediated gene transfer (Belarmino and Mii, 2000; Mishiba et al., 2005; Sreeramanan et al., 2008) and particle bombardment transformation (Anzai et al., 1996; Fumika, 2007). In addition, biolistic transformation is more normally used in orchid gene transformation because of its higher transformation efficiency than Agrobacterium-mediated gene transfer (Chai and Yu, 2007).

The regeneration pathway through culture of inflorescence stem nodes of Phalaenopsis is either via protocormlike bodies (PLBs) or via the proliferation of adventitious shoots. PLBs of several orchid genera such as Dendrobium (Chia et al., 1994; Men et al., 2003; Yu et al., 1999), Phalaenopsis (Anzai et al., 1996), Cymbidium (Yang et al., 1999) and Oncidium (Yee et al., 2008) have been widely used as target tissue for particle bombardment to recover transgenic orchids. However, an Agrobacterium-mediated transformation method was also used to produce orchid PLBs (Chai et al., 2002; Chan et al., 2005; Liau et al., 2003) since the origin of the orchid PLB is from a single somatic cell, that has a high capability of regenerating into a new plant, is easy to root, presumed to be genetically uniform and can be induced efficiently from various somatic tissues including young leaves and stem segments (Chen and Chen, 2007; Yee et al., 2008).

Genes of interest from other orchid genomes or plant species could be introduced for improving commercial traits such as enhancement of fragrance. However in this experiment, it was used the translationally controlled tumour protein (TCTP), as the transgene, because it is a highly conserved protein in all species studied and is a growth related protein believed to play an important role in cell growth and cell division (Bommer and Thiele, 2004). About 20 years ago the TCTP gene was found by three groups interested in translationally regulated genes. They named this protein P21, Q23 and P23, respectively (Gachet et al., 1999). The TCTP name was coined (Gross et al., 1989), based on the fact that the original cDNA was cloned from a human tumour and was regulated at the 
translational level. Later, TCTP was found to be expressed in healthy animal tissues and controlled at both the transcriptional and post-transcriptional levels (Sanchez et al., 1997; Xu et al., 1999).

In plant research, a plant calcium binding TCTP gene has been successfully transformed into a tobacco plant. This transgenic tobacco encoding the TCTP gene grew about $30 \%$ faster than the parental plants during the juvenile growth stage (Kang et al., 2005). Nowadays TCTP has attracted the attention of an increasing number of research workers interested in various biologically and medically relevant processes due to the importance of TCTP for cell cycle progression and malignant transformation. The ultimate goal of this research was to produce a stable transformation of the EgTCTP (Elaeis guineensis TCTP) gene into the PLBs of Phalaenopsis using a biolistic method and to validate its ability to play a role in the regeneration of transgenic orchids.

\section{Materials and methods}

\section{Plasmids}

The pCAMBIA 1302 vector (CAMBIA, Australia), containing an EgTCTP gene as the transgene together with the green fluorescent protein $(m g f p 5)$ reporter gene and the selectable marker hygromycin phosphotransferase $(h p t)$ gene driven by the cauliflower mosaic virus (CaMV) $35 \mathrm{~S}$ constitutive promoter was used in this experiment. This plasmid is approximately $10,549 \mathrm{bp}$ in size.

\section{Plant materials}

PLBs of the white-flowered clones Phalaenopsis Blume were used as the target tissues. These PLBs were multiplied and maintained through four-week sub-culturing intervals in MS basal salt liquid medium (Murashige and Skoog, 1962) supplemented with $15 \%$ coconut water, at $\mathrm{pH} 5.7$ and $25^{\circ} \mathrm{C}$ on a rotary shaker at $100 \mathrm{rpm}$ with a 16 $\mathrm{h}$ photoperiod. Light was provided by fluorescent tubes with a photon flux density of $15 \mu \mathrm{mol} \mathrm{m} \mathrm{m}^{-2} \mathrm{~s}^{-1}$. After four weeks, secondary PLBs were separated using a scalpel into individual PLBs and sub-cultured onto MS basal salt, solid medium. A total of 30 individual PLBs were plated at the centre of a $90-\mathrm{mm}$ diameter Petri dish prior to bombardment. Each Petri dish was bombarded once but each parameter was performed in triplicate.

\section{Biolistic bombardment experiments}

Bombardment experiments were carried out using the Biolistic PDS-1000/He Particle Delivery System (Bio$\mathrm{Rad})$. All the gold microcarriers, macrocarriers, stopping discs, and rupture discs were purchased from Bio-Rad (Hercules), California, USA. Precipitation of the DNA onto gold microcarriers was performed according to the manufacturer's instructions and all the bombardments were performed according to the standard procedures. Bombardments were carried out at the following constant conditions: 1100 psi rupture disc pressure, $11 \mathrm{~mm}$ rupture disc to macrocarrier distance, $9 \mathrm{~cm}$ stopping plate to target tissue distance, $11 \mathrm{~mm}$ macrocarrier to stopping plate distance, $27 \mathrm{~mm} \mathrm{Hg}$ vacuum pressure and using $1 \mu \mathrm{m}$ gold particles as the microcarrier.

Three controls were included, consisting of unbombarded PLBs, PLBs bombarded with microcarriers only (not coated with DNA) and PLBs bombarded with an empty vector. However, the PLBs bombarded with the empty vector might be classified into the same vector group. For the EgTCTP transformed PLBs, they would be the gene group. The bombarded tissues were then incubated at $25^{\circ} \mathrm{C}$ under $16 \mathrm{~h}$ of illumination provided by fluorescent tubes with a photon flux density of $15 \mu \mathrm{mol}$ $\mathrm{m}^{-2} \mathrm{~s}^{-1}$.

\section{Post transformation and selection of putative transformants}

Phalaenopsis PLBs were cultured on fresh MS medium for one week to recover from their bombardment injuries. Hygromycin (HYG) was used as a selective agent in this transformation. All transformed explants were transferred into selective medium containing $20 \mu \mathrm{g} / \mathrm{mL}$ HYG (Mishiba $e t$ al., 2005) for selection of transformants. The newly formed secondary PLBs that survived were further subcultured at four-week intervals on fresh MS solid medium containing the same concentration of HYG as previously for at least 2 months.

Four parameters were assessed to evaluate the regeneration of the Phalaenopsis PLBs, the regeneration frequency was recorded as a mean percentage of explants with shoots (number of regenerated explants/total number of explants *100), the time for initiation of primordial shoots in days, the number of regenerated shoots per explant, and this scoring system was used to evaluate the regeneration efficiency as follows: Negative result $=1$; Below average $=2$; Average $=3$; Above average $=4$ and Excellent $=5$.

\section{GFP detection}

A small section of any surviving orchid was observed for their expression of GFP using a confocal laser scanning microscope (CLSM) equipped with a GFP filter set for excitation between 455 and $490 \mathrm{~nm}$ and for an emission above $500 \mathrm{~nm}$. The expression of the $g f p$ gene was seen as a bright-green fluorescence caused by the presence of GFP in the cells. The difficulty of detecting GFP in the presence of the autofluorescence of the chlorophyll in the PLBs was overcome by using triple colour images acquired by sequentially scanning with settings optimal for the GFP (green), the autofluorescence of the chlorophyll (red) and the surface of organelles (blue). Filter sets tailored to the specific chromophores were used for the GFP (excitation by the $488 \mathrm{~nm}$ argon laser line and its emission collected from 500 to $543 \mathrm{~nm}$, channel 1); the autolluorescence of the chlorophyll (excitation by the $543 \mathrm{~nm}$ argon laser line and its emission collected from 610 to $630 \mathrm{~nm}$, channel 
60

2) and the surface of the organelle (excitation by the 650 $\mathrm{nm}$ argon laser line and its emission collected from 667 to $750 \mathrm{~nm}$, channel 3). Reflected light images were obtained by detection of light at the excitation wavelengths. Serial confocal optical sections were taken at different step sizes. The images of the individual channels were merged and stored as TIF files to facilitate visualization. Monitoring was carried out on random 3 days, in 1, 2, 3, 4 weeks, and 2,3 , and 4 months after bombardment.

Genomic DNA isolation from leaves of regenerated bombarded plantlets

After obtaining the viable Phalaenopsis PLBs, the PLBs were verified for the presence of the transgenes using the PCR technique. According to the manufacturer's instructions of the Genomic DNA Extraction Mini Kit (Plant) (RBC Bioscience Corp., Taiwan), total genomic DNA was extracted from the leaves of regenerated bombarded Phalaenopsis plantlets and used as the DNA template in the PCR reaction.

\section{PCR analysis}

Genomic DNA was extracted from about $100 \mathrm{mg}$ of putative transgenic plants using a Genomic DNA Extraction Mini Kit (Plant). To confirm the presence of the $m g f p 5$ and EgTCTP genes in the transgenic plants, PCR experiments were performed using 2 pairs of specific primers for the GFP and EgTCTP:GFP. For the first PCR primer pair, it was designed to amplify an internal 362 bp $g f p$ fragment: $g f p \mathrm{~F}:$ 5'TCAGTGGAGAGGGTGAAGGTGATG3' and $g f p$ R: 5'CGTTGTGGGAGTTGTAGTTGTATTC3'. The other PCR primer pair, resulting in a $887 \mathrm{bp}$ fragment of $t c t p-g f p$ genes, $t c t p-g f p$ F: 5'ATGGTAATGTTGGTTTATCAG3' and $g f p$ R: 5'CGTTGTGGGAGTTGTAGTTGTATTC3' was used in the PCR reaction.

In the PCR reactions, amplifications of the $g f p$ and tctp-gfp genes were each carried out in a $12.5 \mu \mathrm{L}$ reaction volume containing $1.25 \mu \mathrm{L}$ of $10 \times$ PCR buffer $(10 \mathrm{mM}$ Tris-Cl, $\mathrm{pH} 8.8,50 \mathrm{mM} \mathrm{KCl}$ and $0.8 \%$ Nonidet P40), 0.75 $\mu \mathrm{L}$ of $1.5 \mathrm{mM} \mathrm{MgCl}, 0.25 \mu \mathrm{L}$ of $5 \mathrm{mM}$ dNTP mix (2.5 $\mathrm{mM}$ of each nucleotide dATP, dCTP, dGTP, and dTTP), $0.1 \mu \mathrm{L}$ of $5 \mathrm{U}$ Taq polymerase, $0.25 \mu \mathrm{L}$ of 15 pmole primer each, $1 \mu \mathrm{L}$ of template DNA at $100 \mathrm{ng} / \mu \mathrm{L}$ and $8.65 \mu \mathrm{L}$ nuclease-free water.

The PCR run condition was set to an initial denaturation step of 5 minutes $(\mathrm{min})$ at $94^{\circ} \mathrm{C}$ and subsequent 35 cycles of denaturation $\left(94^{\circ} \mathrm{C}, 50\right.$ seconds), annealing $\left(50^{\circ} \mathrm{C}, 1 \mathrm{~min}\right)$ and extending $\left(72^{\circ} \mathrm{C}, 1 \mathrm{~min}\right)$ followed by a final extending step at $72^{\circ} \mathrm{C}$ for $10 \mathrm{~min}$. The PCR products were electrophoresed in a $1.5 \%$ agarose gel. The size of the amplified fragments were determined with reference to a 100 bp DNA ladder. Gels were stained with ethidium bromide to view fragments.

\section{Statistical analysis}

All experiments were conducted on three different days with at least 30 replicates per treatment. Population sizes varied between experiments, and these sizes are in- dicated together with the experiment results. Variance analysis (ANOVA) was applied to the results wherever indicated using the Sheffe's test at $p \leq 0.05$. The software used was SPSS 13.0 (SPSS Inc., USA) for Windows XP Professional.

\section{Results}

\section{Transformation frequency in the bombardment of Pha-} laenopsis PLBs

The PLBs that survived with green fluorescence spots were calculated as the transformation frequency (\%). No GFP green spots were found in the control group but $83.34 \%$ and $93.34 \%$ of GFP green spots were found in the vector and gene groups, respectively.

\section{Evaluation of the regeneration of Phalaenopsis PLBs} after bombardment

Germination and growth of the Phalaenopsis PLBs during the 1-6 months after bombardment at 1100 psi helium level were compared (Fig. 1). In the first month after bombardment, Phalaenopsis PLBs containing a transformed EgTCTP gene had swollen differentiated tissue while the others were not changed (Fig. 1a). One month later, the EgTCTP transformants regenerated and formed primordial shoots (Fig. 1b). However, in the third month after biolistic transformation, the control and vector alone transformants began to regenerate (Fig. 1c) and continued to grow (Fig. 1d).

To evaluate the regeneration of Phalaenopsis PLBs that was bombarded at 1100 psi helium pressure, four criteria were studied as follows: regeneration frequency, time for initiation of primordial shoots, number of regenerated shoots per explant and regeneration efficiency. Results are summarized in Tab. 1. For the first criteria, the regeneration frequency of the control, vector and gene groups in Phalaenopsis PLBs was 78.34, 80 and 95.66, respectively. During this time the gene transformants took fewer days to initiate primordial shoots than the control and vector transformants. The time for initiation of primordial shoots in the EgTCTP gene transformants took only $55.22 \pm 26.56$ days with $3.78 \pm 1.89$ regenerated shoots per explant. Moreover, the EgTCTP gene transformants achieved the highest score for regeneration efficiency (showing $4.04 \pm 0.88$ "above average" status). With regard to the time required to initiate primordial shoots, the control and vector transformant groups took $83.50 \pm 33.89$ and $61.87 \pm 18.52$ days, respectively. This time was significantly greater than for the gene transformed group. In addition, the numbers of regenerated shoots per explant in the control and vector transformant groups were $1.56 \pm$ 0.51 and $1.14 \pm 0.46$, respectively. For the last criteria, on regeneration efficiency using the scoring system, the two groups of control and vector transformants could be classified into the same level. The score of the control and vector groups were $2.94 \pm 0.52$ and $3.16 \pm 0.76$, respectively which was evaluated as an "average" status. 
Tab. 1 Evaluation of the regeneration parameters of the regenerated Phalaenopsis PLBs from the control, vector and gene groups

\begin{tabular}{cccc}
\hline Evaluation criteria & Control & Vector & Gene \\
\hline Regeneration frequency (\%) & 78.34 & 80 & 95.66 \\
Time of shoot primordial initiation (days) & $83.50 \pm 33.89^{\mathrm{a}}$ & $61.87 \pm 18.52^{\mathrm{b}}$ & $55.22 \pm 26.56^{\mathrm{b}}$ \\
Number of regenerated shoots per explant $_{\text {Regeneration efficiency }}^{*}$ & $1.56 \pm 0.51^{\mathrm{a}}$ & $1.14 \pm 0.46^{\mathrm{a}}$ & $3.78 \pm 1.89^{\mathrm{b}}$ \\
\hline
\end{tabular}

Each value represents the mean of thirty replicates. Means within a row followed by different letters show significant difference as analyzed by Sheffe's test at $\mathrm{P} \leq 0.05$.

${ }^{*}$ Regeneration efficiency was expressed as a score from 1 to 5 (Negative result $=1$; Below average $=2$; Average $=3$; Above average $=4$ and Excellent $=5$ )

Visualization of GFP expression

The successful gene transformation and expression in transformants was examined with a CLSM fitted with a GFP filter set. GFP gene expression was seen as a brightgreen fluorescence caused by the presence of GFP in the cells. In this research, monitoring was carried out at random on bombarded explants from 1 to 4 months after bombardment. All explants expressed bright-green fluorescence even though there was some in the control explants that was probably due to the auto-fluorescence from chloroplasts.
To solve this problem, three different fluorescent, green, red and blue signals were scanned at the same time and the three filters were overlain together. In Fig. 2, the GFP expression, 60 days after bombardment, in the PLBs of Phalaenopsis transformants is illustrated. When the control PLBs (Fig. 2a, b) were compared with the pCAMBIA 1302 transformants (Fig. 2c) and the EgTCTP orchid transformants (Fig. 2d), mgfp5 bright green spots were seen both in the vector alone transformants and the successful gene transformants but none in the controls.
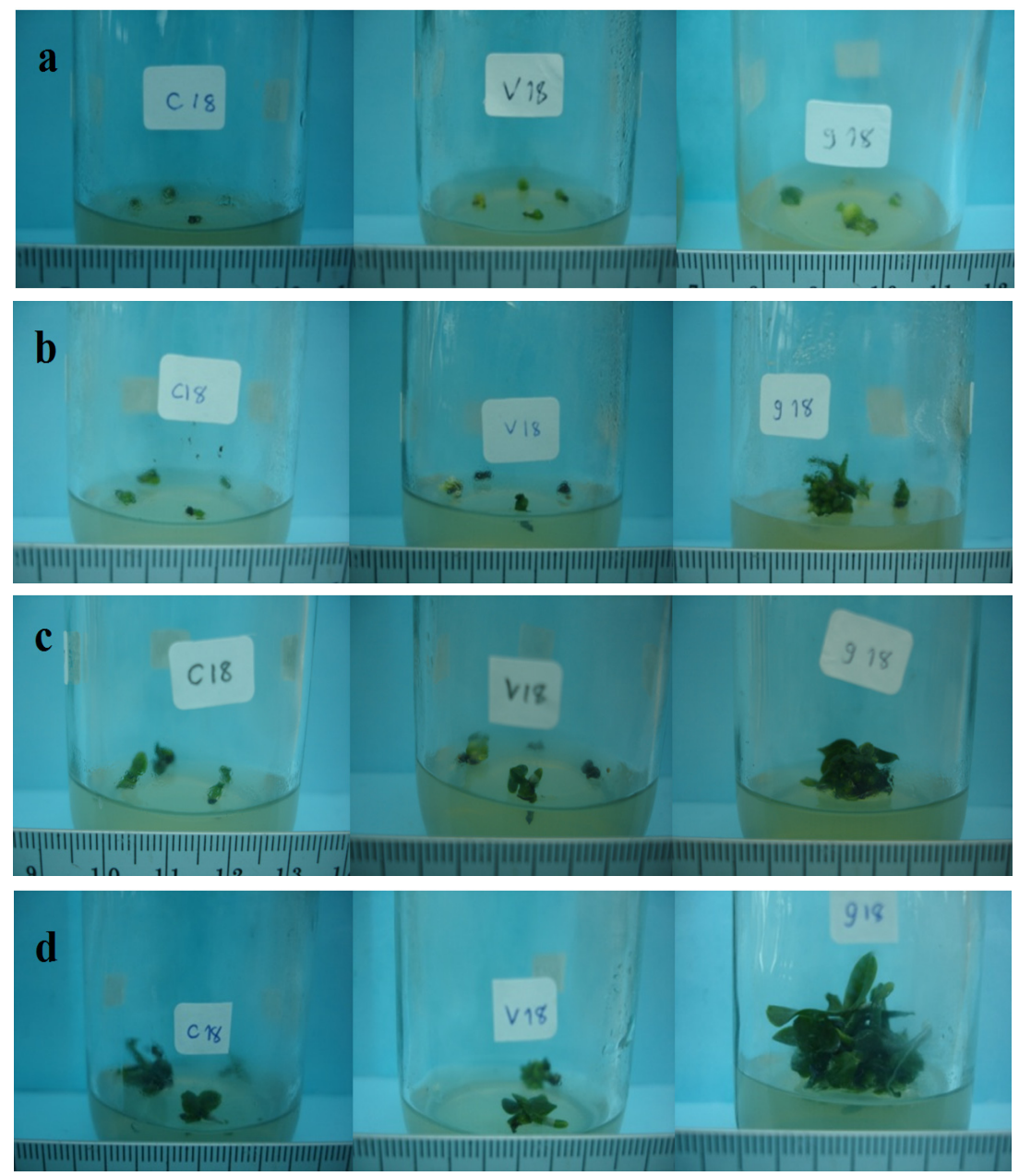

Fig. 1. Growth and development of Phalaenopsis PLBs after bombardment at 1100 psi helium level (from left to right is control, vector-transformed and the EgTCTP gene transformed PLBs, respectively). (a) One-month-old PLBs. (b) Two-month-old PLBs. (c) Three-month-old PLBs and (d) Six-month-old PLBs after transformation 
62
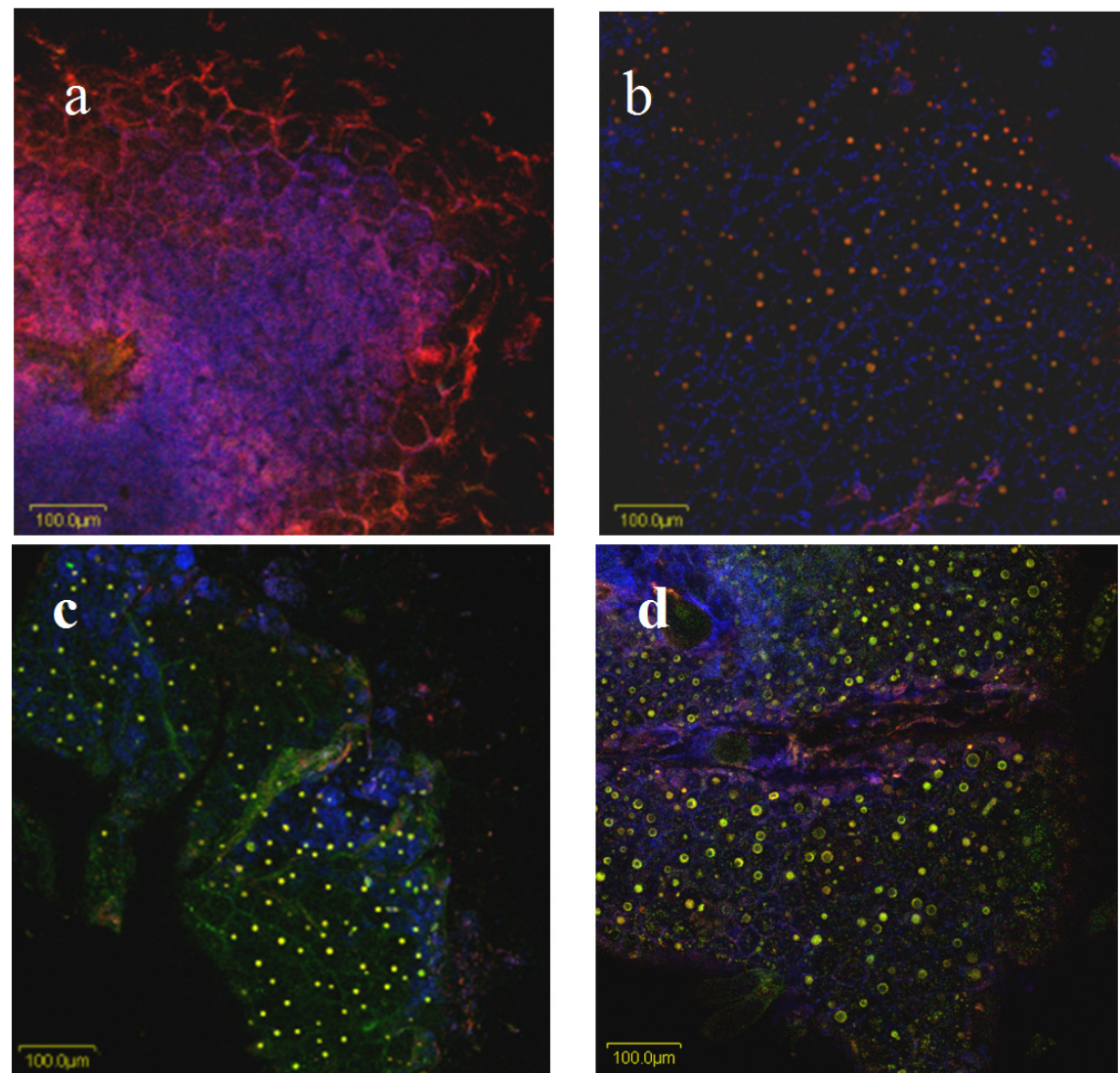

Fig. 2. Localization of GFP in Phalaenopsis PLBs 60 days after bombardment as shown by confocal laser scanning microscope images. $35 \mathrm{~S}$ CaMV-GFP expressed from pCAMBIA1302 vector. (a) Control: umbombarded (b) Control: bombarded without vector and gene $(c)$ Bombarded with vector and (d) Bombarded with transgene plasmid

\section{$\begin{array}{llllllllllllll}1 & 2 & 3 & 4 & 5 & 6 & 7 & 8 & 9 & 10 & 11 & 12 & 13\end{array}$}

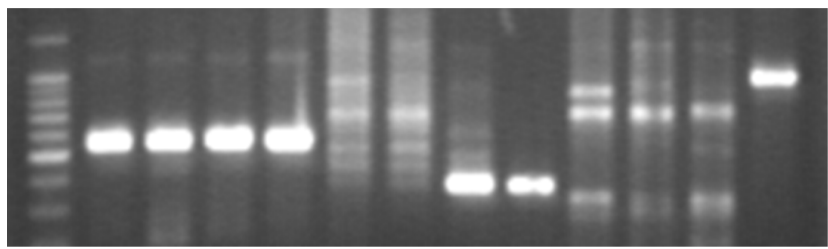

Fig. 3. PCR analysis of transformed Phalaenopsis orchid. Chromosomal DNA was amplified with the specific primer to $18 \mathrm{~s}$ rRNA (Lane 2-5), gfp (Lane 6-9) and $g f p-E g T C T P$ (Lane 10-13) genes. Lane 1 molecular marker DNA, lane 6, 10 negative control (untreated orchid), lane 7, 11 negative control transformed with microcarrier only, lane 8,12 transformed with vector alone, lane 9 positive control transformed with the $g f p$ gene and lane 13 positive control transformed with the $g f p-E g T C T P$ genes

\section{PCR analysis of transformants}

All transformed explants were screened for the presence of the $m g f p 5$ and EgTCTP genes using PCR amplification of fragments within the transferred genes. The chromosomal DNA of Phalaenopsis explants was isolated and used as the template in the PCR reactions later. The result of the PCR reaction is shown in Fig. 3. In transformed Phalaenopsis PLBs, the presence of the $m g f p 5$ transgene pro- duced the expected band at $362 \mathrm{bp}$ whereas the fragment at $887 \mathrm{bp}$ is specific to the recombinant $g f p$-EgTCTP gene. The positive bands of the $g f p$ gene are seen in Fig. 3 (lane 8-9) while the positive band of the $g f p-E g T C T P$ gene was detected in Fig. 3 (lane 13). No amplification was detected in the non-transformed orchids.

\section{Discussion}

Transformation frequency in the bombardment of Phalaenopsis PLBs

In this experiment the transformation frequency in the survived Phalaenopsis PLBs was much higher when compared to that obtained by the bombardment of the PLBs of Phalaenopsis ('Danse' $\times$ 'Happy Valentine'). In this previous work only 7 bialophos-resistant plantlets from 622 bombarded PLBs were obtained (Anzai et al., 1996) and the transformation frequency in the bombarded Dendrobium protocorms was $19.87 \%$ (Suwanaketchanatit et al., 2007). However the percentage transformation frequency in the present work with Phalaenopsis PLBs bombardment was nearly as high as that obtained by the bombardment of Cymbidium PLBs that produced about $85 \%$ of GUS positive shoots (Yang et al., 1999). These results support 
the transformation efficiency of this Phalaenopsis PLBs bombardment.

\section{Regeneration evaluation of Phalaenopsis PLBs after bombardment}

As far as the regeneration properties are concerned, the EgTCTP transformed Phalaenopsis PLBs using the optimal helium pressure at 1100 psi promoted the regeneration frequency and efficiency as well as a shorter time for initiation of primordial shoots and produced more regenerated shoots per PLBs. In an evaluation of the number of regenerated shoots per explant, after being bombarded the explants with the EgTCTP gene produced the highest shoot number compared to the control and vector groups. For the evaluation of regeneration efficiency, the status of the EgTCTP orchid transformants was in the above average' level. These results were in agreement with transgenic tobacco which had been transformed with the ntTCTP gene using the Agrobacterium-mediated method grew 30\% higher than the parental plants during the juvenile growth stage (Kang et al., 2005). The present results also clearly demonstrated the importance of the role of EgTCTP which also seems to assist with the transformation process and provides benefits for plant growth and regeneration.

\section{Visualization of GFP expression}

GFP monitoring was an effective tool for screening the transformed explants because the $g f p$ gene offers advantages such as any transformants do not contain antibiotic resistance genes to use for selection and its presence also avoids the need to use a destructive GUS assay for identification. It was therefore relatively easy to establish if transformation had occurred by looking for the green fluorescence because GFP was part of the pCAMBIA 1302 plasmid that also contained the EgTCTP gene. The expression of GFP was in agreement with Tee and Maziah (2005) who reported that the GFP expression rate transformed into Dendrobium Sonia 17 was higher than that for the GUS under the control of the same promoter based on the GUS or GFP spot counts. Almost all bombarded PLBs of orchid showed many bright green spots from the GFP fluorescence inside the cells compared to the controls due to the GFP expression under control of the strong constitutive CaMV $35 S$ promoter. Normally, the brightness of fluorescence was maintained at full intensity during the subculture. This indicated that explants and their plasmids were able to proliferate under HYG selective conditions. However, interference by plant chlorophyll with the GFP fluorescence was a complication for evaluation. By preventing autochlorophyll fluorescence in orchid PLBs, the sequential scanning of the triple color image method could easily detect the difference between GFP fluorescence and the autofluorescence of chlorophyll. In addition, the red autofluorescence of the chlorophyll interacted with the green fluorescence of the GFP to make the plants transformed with GFP appear yellow under
UV light. Furthermore, there are other methods able to distinguish GFP from endogenous autofluorescence such as using optimized filter sets, dual-wavelength differential fluorescence correction, fluorescence polarization, use of image analysis software, autofluorescence quenching, the use of spectrally different GFP mutants, etc (Billington and Knight, 2001). Thus, the GFP-based visual selection has made it possible and simple to detect and select transgene-carrying tissues.

In this study, for the first time, the $m g f p 5$ gene was used in transformation of Phalaenopsis PLBs with a high efficiency. The ability of the above tissues to express GFP activities more than 4 months post-bombardment further indicated that the transgene had been successfully and stably integrated into the genome of the putative transformants. Nevertheless, the stable integration of the EgTCTP gene after integrating into the orchid cells received further proof via PCR analysis.

\section{PCR analysis of transformants}

In the past, several research studies in orchids (Anzai et al., 1996; Chia et al., 1994; Men et al., 2003; Tee and Maziah, 2005; Suwanaketchanatit et al., 2007; Yang et al., 1999; Yu et al., 1999; Yee et al., 2008) have shown the stable integration of transgenes via biolistic transformation although Janna et al. (2006) reported only a transient expression of the transgenes. Eventually, the presence and integration of the $m g f p 5$ transgene via the particle bombardment method was established in other plants genome such as petunia (Garabagi and Strommer, 2000), papaya (Zhu et al., 2004) and high oleic acid sunflower (Mohamed et al., 2006). With regard to the PCR analysis in the Phalaenopsis explants in this study, the obtained PCR bands confirmed the presence of $m g f p 5$ and EgTCTP sequences. Therefore this observation proves the stable integration of the EgTCTP gene into the transformed orchids.

\section{Acknowledgements}

We thank the Scientific Equipment Center, Prince of Songkla University for their invaluable support with the Biolistic PDS-1000/He particle device and the confocal laser scanning microscope. This research was financially supported by the Graduate School, Prince of Songkla University, Thailand. Also thanks to Dr. Brian Hodgson for his assistance with the English.

\section{References}

Anzai H, Ishii Y, Shichinohe M, Katsumata K, Nojiri C, Morikawa H, Tanaka M (1996). Transformation of Phalaenopsis by particle bombardment. Plant Tissue Cult Lett 3:265-271.

Belarmino MM, Mii M (2000). Agrobacterium-mediated genetic transformation of a Phalaenopsis orchid. Plant Cell Rep 19:435-442.

Billington N, Knight AW (2001). Seeing the wood through 
64

the trees: a review of techniques for distinguishing green fluorescent protein from endogenous autofluorescence. Anal Biochem 291:175-197.

Bommer UA, Thiele BJ (2004). The translationally controlled tumour protein (TCTP). Inter J Biochem Cell Biol 36:379385 .

Chai ML, Xu CJ, Senthil KK, Kim JY, Kim DH (2002). Stable transformation of protocorm-like bodies in Phalaenopsis orchid mediated by Agrobacterium tumefaciens. Sci Hortic 96:213-224.

Chai D, Yu H (2007). Recent advances in transgenic orchid production. Orchid Sci Biotechnol 1:34-39.

Chan YL, Lin KH, Sanjaya, Liao LJ, Chen WH, Chan MT (2005). Gene stacking in Phalaenopsis orchid enhances dual tolerance to pathogen attack. Transgenic Res 14:279-288.

Chen WH, Chen HH (2007). Orchid biotechnology. World Scientific Publishing Co. Ltd, Singapore

Chia TF, Chan YS, Chua NH (1994). The firefly luciferase gene as a noninvasive reporter for Dendrobium transformation. Plant J 6:441-446.

Fumika U (2007). Expression analysis of Phalaenopsis orchid introduced disease resistant gene Chitinase. Master thesis, Obihiro University, Japan

Gachet Y, Tournier S, Lee M, Lazaris-Karatzas A, Poulton T, Bommer UA (1999). The growth-related, translationally controlled protein P23 has properties of a tubulin binding protein and associates transiently with microtubules during the cell cycle. J Cell Sci 112:1257-1271.

Garabagi F, Strommer J (2000). Green fluorescent protein as an all-purpose reporter in petunia. Plant Mol Biol Rep 18:219226.

Gross B, Gaestel M, Böhm H, Bielka H (1989). cDNA sequence coding for a translationally controlled human tumor protein. Nucleic Acids Res 17:8367.

Janna OA, Maziah M, Ahmad Parveez GKA, Saleh K (2006). Factor affecting delivery and transient expression of $\beta$-glucuronidase gene in Dendrobium Sonia protocorm like-body. Afr J Biotechnol 5:88-94.

Kang JG, Yun J, Song PS, Park CM (2005). Transgenic plant transformed with a translationally controlled tumor protein (TCTP) gene. United States Patent no. US 6,946,294 B2 (Sep. 20 ${ }^{\text {th }}, 2005$ )

Liau CH, You SJ, Prasad V, Hsiao HH, Lu JC, Yang NS, Chan MT (2003). Agrobacterium tumefaciens-mediated transformation of an Oncidium orchid. Plant Cell Rep 21:993-998

Men S, Ming X, Wang Y, Liu R, Wei C, Li Y (2003). Genetic transformation of two species of orchid by biolistic bombardment. Plant Cell Rep 21:592-598.
Mishiba KI, Chin DP, Mii M (2005). Agrobacterium-mediated transformation of Phalaenopsis by targeting protocorms at an early stage after germination. Plant Cell Rep 24:297303.

Mohamed SH, Boehm R, Schnabl H (2006). Stable genetic transformation of high oleic Helianthus annuus L. genotypes with high efficiency. Plant Sci 171:546-554.

Murashige T, Skoog F (1962). A revised medium for rapid growth and bioassays with tobacco tissue cultures. Physiol Plant 15:473-497.

Sanchez JC, Schaller D, Ravier F, Golaz O, Jaccoud S, Belet M, Wilkins MR, James R, Deshusses J, Hochstrasser D (1997). Translationally controlled tumor protein: a protein identified in several non tumoral cells including erythrocytes. Electrophoresis 18:150-155.

Sreeramanan S, Vinod B, Sashi S, Xavier R (2008). Optimization of the transient Gusa gene transfer of Phalaenopsis Violacea orchid via Agrobacterium Tumefaciens: an assessment of factors influencing the efficiency of gene transfer mechanisms. Adv Nat Appl Sci 2:77-88.

Suwanaketchanatit C, Piluek J, Peyachoknagul S, Huehne PS (2007). High efficiency of stable genetic transformation in Dendrobium via microprojectile bombardment. Biologia Plantarum 51:720-727.

Tee CS, Maziah M (2005). Optimization of biolistic bombardment for Dendrobium Sonia 17 calluses using GFP and GUS as the reporter system. Plant Cell Tissue Organ Cult 80:77-89.

Xu A, Bellamy AR, Taylor JA (1999). Expression of translationally controlled tumor protein is regulated by calcium at both the transcriptional and post-transcriptional level. Biochem J 342:683-689.

Yang J, Lee H, Shin DH, Oh SK, Seon JH, Paek KY, Han KH (1999). Genetic transformation of Cymbidium orchid by particle bombardment. Plant Cell Rep 18:978-984.

Yee NG, Abdullah JO, Mahmood M, Basiron N (2008). Cotransfer of $g f p$, CHS and $h p t \mathrm{II}$ genes into Oncidium Sharry Baby PLB using the biolistic gun. Afr J Biotechnol 7:26052617.

Yu Z, Chen M, Nie L, Lu H, Ming XT, Zheng H, Qu LJ, Chen Z (1999). Recovery of transgenic orchid plants with hygromycin selection by particle bombardment to protocorms. Plant Cell Tissue Organ Cult 58:87-92.

Zhu YJ, Agbayani R, Moore PH (2004). Green fluorescent protein as a visual selection marker for papaya (Carica papaya L.) transformation. Plant Cell Rep 22:660-667. 